\title{
Aerosol Pollution from Small Combustors in a Village
}

\author{
A. Zwozdziak, ${ }^{1}$ L. Samek, ${ }^{2}$ I. Sowka, ${ }^{1}$ L. Furman, ${ }^{2}$ and M. Skrętowicz ${ }^{1}$ \\ ${ }^{1}$ Institute of Environmental Protection Engineering, Wroclaw University of Technology (WUT), Wybrzeze Wyspiańskiego 27, \\ 50-370 Wroclaw, Poland \\ ${ }^{2}$ Faculty of Physics and Applied Computer Science, AGH University of Science and Technology, 30 Mickiewicza Avenuo, \\ 30-059 Krakow, Poland \\ Correspondence should be addressed to A. Zwozdziak, anna.zwozdziak@pwr.wroc.pl
}

Received 28 October 2011; Accepted 29 November 2011

Academic Editor: Costas Varotsos

Copyright ( 92012 A. Zwozdziak et al. This is an open access article distributed under the Creative Commons Attribution License, which permits unrestricted use, distribution, and reproduction in any medium, provided the original work is properly cited.

Urban air pollution is widely recognized. Recently, there have been a few projects that examined air quality in rural areas (e.g., AUPHEP project in Austria, WOODUSE project in Denmark). Here we present the results within the International Cooperation Project RER/2/005 targeted at studying the effect of local combustion processes to air quality in the village of Brzezina in the countryside north-west of Wroclaw (south western Poland). We identified the potential emission sources and quantified their contributions. The ambient aerosol monitoring ( $\mathrm{PM}_{10}$ and elemental concentrations) was performed during 4 measurement cycles, in summer 2009, 2010 and in winter 2010, 2011. Some receptor modeling techniques, factor analysis-multiple linear regression analysis (FA-MLRA) and potential source localization function (PSLF), have been used. Different types of fuel burning along with domestic refuse resulted in an increased concentration of $\mathrm{PM}_{10}$ particle mass, but also by an increased in various other compounds $\left(\mathrm{As}, \mathrm{Pb}, \mathrm{Zn}\right.$ ). Local combustion sources contributed up to $80 \%$ to $\mathrm{PM}_{10}$ mass in winter. The effect of other sources was small, from 6 to $20 \%$, dependently on the season. Both $\mathrm{PM}_{10}$ and elemental concentrations in the rural settlement were comparable to concentrations at urban sites in summer and were much higher in winter, which can pose asignificant health risk to its inhabitants.

\section{Introduction}

Atmospheric air contains numerous toxic substances as a result of both natural occurrence and anthropogenic activities. Among others, also aerosols are very important. When the air is contaminated by aerosols in general, and heavy metals in particular, it becomes of threat to human health because aerosols can be introduced into the body primarily through the respiratory system and then can enter the human blood circulation rapidly. It leads to an increased risk of certain cardiovascular and pulmonary diseases. Recently, in the USA and Europe, it has been found out that mortality in urban regions and cardiovascular hospital admissions are correlated with the atmospheric levels of fine particles [1-3].

Air particulate matter can also cause chemical deterioration and soiling of structural materials of building, statues, and even paintings. The subject of eventual damages of cultural heritage items through deposition of particles and absorption of gases has already been discussed in the relevant literature $[4,5]$.
Although the levels of several pollutants have evidently decreased in many urban areas in Europe, this trend seems to be questionable in rural and semirural areas. It is observed that people in urban areas are moving to favor more healthy rural living, thus it is important to obtain some information on the levels and chemical composition of airborne particulate matter containing trace metals in rural settlements. The Technical Cooperation Project RER/2/005 on "Characterizing Seasonal Variations in Elemental Particulate Matter Concentrations in European Urban and Rural Areas under Different Climatic Conditions" was started in 2009 as a dual site approach with one urban and one rural site. The urban site should be representative for "urban background", that is, residential area without direct influence of traffic. The acceptable rural location should be situated in a small town/village. The settlement should be characterized by use of solid fuel for domestic heating. The purpose of the campaigns was to assess the effect of local combustion processes on air quality. Over two-year period (2009-2011), continuous monitoring of $\mathrm{PM}_{10}$ with consequent elemental 
characterization of the aerosols was conducted for two weeks per site per season for both years. Additionally, receptor modeling techniques have been used to identify and quantify the potential sources contributing to $\mathrm{PM}_{10}$ mass.

\section{Materials and Methods}

Brzezina $\left(51^{\circ} 12^{\prime} 12^{\prime \prime} \mathrm{N}, 16^{\circ} 49^{\prime} 38^{\prime \prime} \mathrm{E}\right)$ is a small village of approximately 350 inhabitants, surrounded by agricultural areas, and with no local industry. The nearest industrial site is Wroclaw (634 000 inhabitants), approximately $20 \mathrm{~km}$ southeast and copper mining and processing plants, about $50 \mathrm{~km}$ to the west and northwest of the site. Brzezina was selected as a suitable site because it is a typical bedroom community with all houses equipped with small combustors for burning different kind of fuels. Measurements were conducted in a garden at the outskirts of the village (Figure 1). The nearest surroundings of the measurement site were meadows and private detached houses with gardens. The small streets in a village were mainly used by cars for a few vehicles per hour during the day.

Aerosol $\mathrm{PM}_{10}$ was collected for two weeks in August 2009, July/August 2010 and in February 2010, February 2011 on a daily basis with a TCR TECORA Sampler (Model Charlie $\mathrm{HV}$, Italy). The sampling rate was set at $2.3 \mathrm{~m}^{3} / \mathrm{h}$. Sampling substrates were Teflon-membrane $47 \mathrm{~mm}$ diameter filters (Whatman PTFE, 2 um pore size). Filters were weighted to evaluate the $\mathrm{PM}_{10}$ mass on a microbalance in a controlled clean room. Filter weight before and after sampling was obtained as the average of three measurements. Concentrations of following elements were measured: $\mathrm{K}, \mathrm{Ca}, \mathrm{Cr}, \mathrm{Mn}$, $\mathrm{Fe}, \mathrm{Cu}, \mathrm{Zn}, \mathrm{Br}, \mathrm{Pb}$, and As. Chemical analyses were performed by X-Ray Fluorescence Analysis in the laboratory of Faculty of Physics and Applied Computer Science, AGH university of Science and Technology, Krakow, Poland. The University is equipped with the Energy Dispersive X-Ray Fluorescence Spectrometer. The details of sampling and the accuracy of analytical methods are given in [6]. In our source apportionment studies, only elements that were above the detection limit (DL) in over $50 \%$ of the samples were included.

For further identification of $\mathrm{PM}_{10}$ emission sources, PCA analysis (STATISTICA software) was applied to the element concentration data obtained in the rural site. Then, multilinear regression analysis was performed for evaluation of the contribution of each source group to the PM mass concentration. The method was developed by Thurston and Spengler [7] in which FA was conducted, absolute zero values calculated and applied to give absolute FA scores, followed by a regression of the mass to apportion $\mathrm{PM}_{10}$ to source categories and locations under study. Details of source apportionment methodology and results are presented in Almeida et al. $[8,9]$.

Meteorological parameters measured during the period of the field studies were wind speed and direction, temperature, relative humidity, pressure and precipitation, which were obtained from Wroclaw Airport, Starachowice about $10 \mathrm{~km}$ in the south direction. The backwards trajectories of the air masses were calculated by the HYSPLIT model [10] run by NOAA (http://www.arl.noaa.gov/).

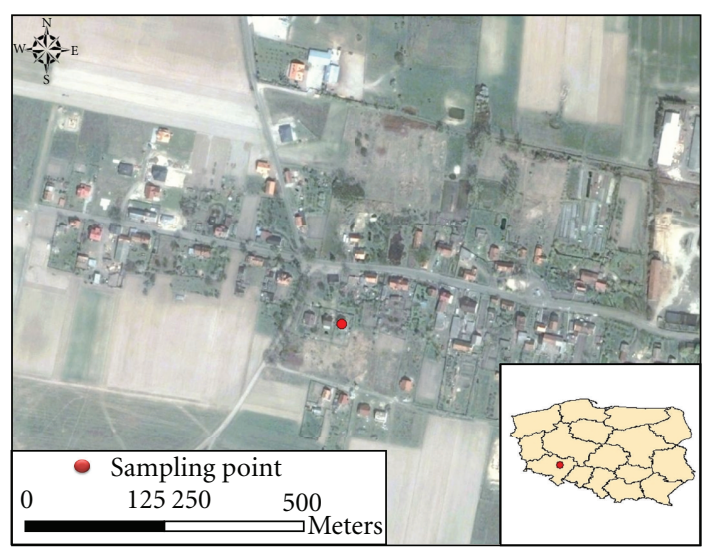

FIGURE 1: Location of the sampling site in Brzezina, Poland (source: "Bing Maps Aerial").

\section{Results and Discussion}

3.1. General Weather Conditions during Field Studies. Main meteorological conditions for the following field studies are shown in Table 1. Summer 2009 as well as summer 2010 was characterised by sunny weather and high air temperature. In winter 2010 and 2011, the weather conditions were mostly sunny, however, with foggy and snowy episodes. During summer seasons, the maximum and minimum temperatures were found to be similar; the differences did not exceed $3^{\circ} \mathrm{C}$. The relative humidity and wind conditions were also comparable for two measurement periods. During the winter periods, the temperature was noticeably lower in 2010 than 2011 and with higher frequency of precipitation events (snow). The winter measurement period in 2011 was dominated by stronger western winds, thus with greater air ventilation potential than in winter 2010. Low variable winds prevailed for most of measurement days in 2010.

Figure 2 shows the frequencies of wind directions-calculated on the basis 1-hour wind data for summer and winter periods. Wind roses are a popular way to represent local transport information. The data show that (1) eastern and southeastern winds dominated in summer 2009; (2) comparable southeastern and northwestern components occurred during summer 2010; (3) winds distinctly changed direction during winter 2010; (4) western winds dominated in winter 2011. Different wind conditions give one of the explanations for the strong variation of the $\mathrm{PM}_{10}$ concentration.

3.2. $P M_{10}$ and Elemental Concentrations. Average daily $\mathrm{PM}_{10}$ and elemental concentrations are summarized in Table 2. As shown in Table 2, very high concentrations of $\mathrm{PM}_{10}$ were observed during the cold seasons, 91.2 and $54.7 \mu \mathrm{g} / \mathrm{m}^{3}$ in 2010 and 2011, respectively. The $\mathrm{PM}_{10}$ concentrations for 2009 and 2010 summer field studies were considerably lower than observed during the cold seasons, (all summer data: $21.6 \pm 8.0 \mu \mathrm{g} / \mathrm{m}^{3}$; all winter data: $\left.75.7 \pm 43.3 \mu \mathrm{g} / \mathrm{m}^{3}\right)$. The strong seasonal variability was also monitored in rural sites in the Czech Republic $[11,12]$ and was explained by the local 
TABLE 1: Meteorological conditions during the field studies.

\begin{tabular}{lcccc}
\hline Parameter & & \multicolumn{3}{c}{ Date } \\
& $8-10.08 ; 16-27.08 .09$ & $29.07-12.08 .10$ & $10-24.02 .10$ & $1 \div 11.02 ; 2 \div 5.03 .11$ \\
\hline$t_{\max },{ }^{\circ} \mathrm{C}$ & $26 \div 33$ & $26 \div 34$ & $-2 \div 10$ & $-4 \div 12$ \\
$t_{\min },{ }^{\circ} \mathrm{C}$ & $9 \div 16$ & $12 \div 18$ & $-14 \div 0$ & $-10 \div 10$ \\
Humidity, $\%$ & $67 \div 82$ & $62 \div 94$ & $74 \div 92$ & $60 \div 96$ \\
Precipitation events & $17,21 / 22$ & $3,7 / 8$ & $11,13,15,20,21,23,24$ & 4.02 \\
Wind conditions & $\mathrm{E}-\mathrm{SE} ;<2 \mathrm{~m} / \mathrm{s}$ & $\mathrm{E}-\mathrm{SE},<2 \mathrm{~m} / \mathrm{s}$ & Variable, $<2 \mathrm{~m} / \mathrm{s}$ & $\mathrm{W},<5 \mathrm{~m} / \mathrm{s}$ \\
\hline
\end{tabular}

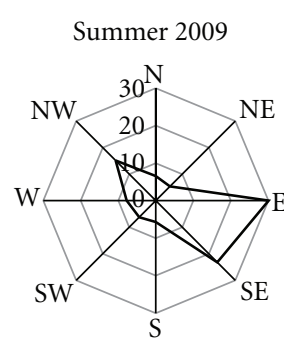

(a)

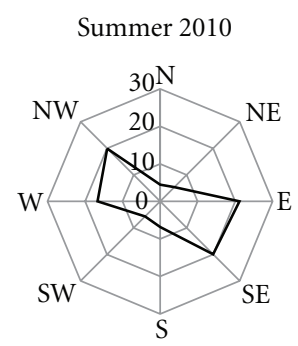

(b)

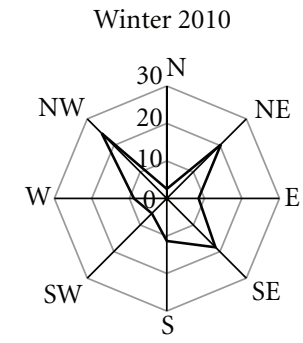

(c)

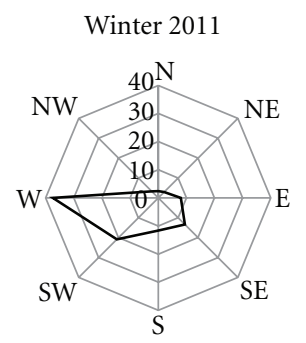

(d)

Figure 2: Wind direction frequency (\%) for summer 2009 (a), 2010 (b) and winter 2010 (c), 2011 (d) field studies.

emissions from heating facility sources during the winter months. On the contrary in Austria, at the rural site $30 \mathrm{~km}$ west of Vienna, the concentrations of $\mathrm{PM}_{10}$ showed no strong variability during the seasons of the year and the long-term average was $21.1 \mu \mathrm{g} / \mathrm{m}^{3}$ [13]. However, Gomiscek et al. [14] reported that concentrations of $\mathrm{PM}_{10}$ were above $60 \mu \mathrm{g} / \mathrm{m}^{3}$ in some episodic situations at the same rural site in Austria.

By comparing the present results with data collected in urban background air monitoring stations in Wroclaw [15], we could observe comparable $\mathrm{PM}_{10}$ concentrations in nonheating seasons, while values measured in Wroclaw during heating seasons were much lower than those observed in Brzezina and ranged between 28 and $32 \mu \mathrm{g} / \mathrm{m}^{3}$. High $\mathrm{PM}_{10}$ concentrations in Brzezina, higher than in the city, were clearly governed by the local emission from heating facility sources and to some extent to traffic. Particularly, that levels remained high during the whole winter sampling periods. The highest $\mathrm{PM}_{10}$ mass concentrations were monitored in February, 2010. Temperature remained very cold on these days (minimum: $-14^{\circ} \mathrm{C}$ ), thus $\mathrm{PM}_{10}$ peak concentrations were most likely due to increased emission from heating sources. Even observed isolated snow events in winter 2010 with low wind speed (wind gust) did not reduce high dust concentrations. This phenomenon was also indicative for the local origin of $\mathrm{PM}_{10}$. Generally storms reduce air pollution; however, the discussion of this problem is out of the scope of this paper.

The European Union air quality daily $\mathrm{PM}_{10}$ standard is $50 \mu \mathrm{g} / \mathrm{m}^{3}$, that can be exceeded a maximum of 35 days per year. 11 daily $\mathrm{PM}_{10}$ concentrations were higher than the limit value, which represents almost $80 \%$ of the sampling days in February 2010. The corresponding data for February 2011 was $45 \%$ (6 cases). In the case of trace elements, only some are discussed at policy level in the European Union. Currently, there are annual target values for $\mathrm{Ni}, \mathrm{As}, \mathrm{Cd}$ (they enter into force 1.1.2012) and a limit value for $\mathrm{Pb}$. These elements should not exceed the annual standard of $20 \mathrm{ng} / \mathrm{m}^{3}$, $6 \mathrm{ng} / \mathrm{m}^{3}, 5 \mathrm{ng} / \mathrm{m}^{3}$, and $0.5 \mu \mathrm{g} / \mathrm{m}^{3}$, respectively. For $\mathrm{Pb}$, the standard was much higher than the observed concentrations. $\mathrm{Cd}$ and $\mathrm{Ni}$ were not detected in the samples. Nevertheless, the reported levels for As in some samples exceeded $6 \mathrm{ng} / \mathrm{m}^{3}$.

As can be seen from Table 2, there were distinct differences in trace element concentrations associated with $\mathrm{PM}_{10}$ among four measurement periods. Concentrations rose in winter seasons, reaching values up to 4 times higher than in summer. For example, the average concentrations of $\mathrm{Pb}$ were $12,5 \mathrm{ng} / \mathrm{m}^{3}$ and $29.8 \mathrm{ng} / \mathrm{m}^{3}$ in summer studies, and 85.9 and $52.0 \mathrm{ng} / \mathrm{m}^{3}$ in winter periods. In the case of $\mathrm{Zn}$, the mean concentrations were 44 and 26 during summertime, and 199 and $119 \mathrm{ng} / \mathrm{m}^{3}$ in winter studies. Strong fluctuations of the concentrations can be demonstrated by the standard deviation divided by the mean. As and $\mathrm{Cr}$ were the elements with a coefficient above 1.0. The average concentrations of these elements should be considered as indicative since there was a high uncertainty on the XRF values (they were often below the detection limit). Nevertheless, they appeared episodically in high concentrations in ambient aerosol, indicating that specific sources were at play. Different wind conditions together with variable other weather parameters (Table 1) could only partly explain significant variations in observed elemental concentrations.

3.3. Receptor Modeling Techniques. Seasonal trends in $\mathrm{PM}_{10}$ and some trace elements concentrations can suggest that local combustion sources are predominantly active during wintertime. Some simple techniques, as factor analysis (FA), 
TABLE 2: Average daily $\mathrm{PM}_{10}$ and elemental concentrations with standard deviation at the rural site (Brzezina) for following measurement periods.

\begin{tabular}{lcccc}
\hline Element & Summer 2009 & Summer 2010 & Winter 2010 & Winter 2011 \\
\hline $\mathrm{K}, \mathrm{ng} / \mathrm{m}^{3}$ & $324 \pm 170$ & $401 \pm 98$ & $648 \pm 327$ & $442 \pm 346$ \\
$\mathrm{Ca}, \mathrm{ng} / \mathrm{m}^{3}$ & $474 \pm 342$ & $370 \pm 202$ & $376 \pm 145$ & $505 \pm 342$ \\
$\mathrm{Cr}, \mathrm{ng} / \mathrm{m}^{3}$ & $<\mathrm{DL}^{*}$ & $<\mathrm{DL}^{*}$ & $30 \pm 32$ & $22.3 \pm 18.9$ \\
$\mathrm{Mn}, \mathrm{ng} / \mathrm{m}^{3}$ & $37.1 \pm 21.2$ & $15.6 \pm 11.6$ & $44.2 \pm 37.3$ & $34.8 \pm 21.8$ \\
$\mathrm{Fe}, \mathrm{ng} / \mathrm{m}^{3}$ & $630 \pm 367$ & $306 \pm 198$ & $500 \pm 368$ & $558 \pm 348$ \\
$\mathrm{Cu}, \mathrm{ng} / \mathrm{m}^{3}$ & $10.9 \pm 5.1$ & $10.7 \pm 3.2$ & $32.2 \pm 19.3$ & $16.1 \pm 9.5$ \\
$\mathrm{Zn}, \mathrm{ng} / \mathrm{m}^{3}$ & $44 \pm 33$ & $26 \pm 14$ & $199 \pm 118$ & $119 \pm 93$ \\
$\mathrm{Br}, \mathrm{ng} / \mathrm{m}^{3}$ & $7.5 \pm 1.9$ & $2.8 \pm 1.6$ & $28.3 \pm 16.3$ & $19.4 \pm 12.1$ \\
$\mathrm{~Pb}, \mathrm{ng} / \mathrm{m}^{3}$ & $12.5 \pm 8.9$ & $29.8 \pm 20.7$ & $85.9 \pm 52.8$ & $52.0 \pm 45.5$ \\
$\mathrm{As}, \mathrm{ng} / \mathrm{m}^{3}$ & $3.5 \pm 4.4$ & $<\mathrm{DL}$ & $4.3 \pm 5.17$ & $4,9 \pm 5.4$ \\
$\mathrm{PM}\left(10, \mu \mathrm{g} / \mathrm{m}^{3}\right.$ & $23.9 \pm 8.4$ & $19.4 \pm 7.0$ & $91.2 \pm 49.5$ & $54.7 \pm 38.8$ \\
\hline
\end{tabular}

* Below detection limit.

TABLE 3: VARIMEX normalized rotated factor loadings for a factor analysis on Brzezina $\mathrm{PM}_{10}$ data set. Loadings for which the absolute value is greater than 0.700 are indicated in italic.

\begin{tabular}{|c|c|c|c|c|c|c|c|c|c|c|c|c|}
\hline \multirow[b]{2}{*}{ El. } & \multicolumn{3}{|c|}{ Summer 2009} & \multicolumn{3}{|c|}{ Summer 2010} & \multicolumn{3}{|c|}{ Winter 2010} & \multicolumn{3}{|c|}{ Winter 2011} \\
\hline & $\mathrm{F} 1$ & $\mathrm{~F} 2$ & Com. & $\mathrm{F} 1$ & $\mathrm{~F} 2$ & Com. & F1 & $\mathrm{F} 2$ & Com. & $\mathrm{F} 1$ & $\mathrm{~F} 2$ & Com. \\
\hline $\mathrm{K}$ & 0,92 & 0,10 & 0,85 & 0.84 & 0.29 & 0.90 & 0,79 & 0,42 & 0,80 & 0,95 & 0,11 & 0,97 \\
\hline $\mathrm{Ca}$ & 0,98 & 0,08 & 0,97 & 0.86 & 0.33 & 0.96 & 0,63 & 0,54 & 0,68 & 0,78 & 0,23 & 0,94 \\
\hline $\mathrm{Cr}$ & 0,47 & 0,05 & 0,23 & - & - & - & 0,71 & 0,05 & 0,51 & 0.10 & 0,95 & 0,89 \\
\hline $\mathrm{Mn}$ & 0,95 & 0,02 & 0,91 & 0.88 & 0.05 & 0.80 & 0,87 & 0,22 & 0,81 & 0,39 & 0,88 & 0,98 \\
\hline $\mathrm{Fe}$ & 0,96 & 0,21 & 0,96 & 0.88 & 0.33 & 0.94 & 0,90 & 0,21 & 0,86 & 0,65 & 0,73 & 0,98 \\
\hline $\mathrm{Cu}$ & 0,48 & 0,54 & 0,53 & 0.37 & 0.91 & 0.95 & 0,82 & 0,07 & 0,68 & 0,70 & 0,54 & 0,96 \\
\hline $\mathrm{Zn}$ & 0,92 & 0,03 & 0,84 & 0.78 & 0.29 & 0.94 & 0,95 & 0,16 & 0,94 & 0,95 & 0,22 & 0,98 \\
\hline $\mathrm{Br}$ & 0,86 & 0,20 & 0,77 & 0.36 & 0.38 & 0.43 & 0,93 & 0,11 & 0,88 & 0,88 & 0,32 & 0,94 \\
\hline $\mathrm{Pb}$ & 0,87 & 0,12 & 0,80 & 0.16 & 0.94 & 0.96 & 0,73 & 0,45 & 0,74 & 0,93 & 0,15 & 0,98 \\
\hline As & 0,09 & 0,95 & 0,91 & - & - & - & 0,07 & 0,85 & 0,74 & 0,82 & 0,02 & 0,90 \\
\hline Var.,\% & 64 & 13 & 77 & 57 & 20 & 77 & 61 & 15 & 76 & 57 & 30 & 87 \\
\hline S.C., $\%$ & 61 & 12 & & 31 & 15 & & 79 & 6 & & 55 & 20 & \\
\hline
\end{tabular}

Com. is the communality: the proportion of a variable's variance explained by a factor structure.

Var., \% is the total variance explained by a factor in percent.

S.C., \% is average source contribution to $\mathrm{PM}_{10}$ mass concentration in percent.

allow deriving information whether a combustion is the only pollution source in rural areas and to which extent trace metals are originating from this source. Table 3 gives the matrixes of the loadings after rotation for the data from the following field campaigns. The matrixes can be used to combine sources with the rotated factors. There are strongly correlated compounds observed for each factor. Two sources accounted for $77 \%$ of the total variance for the summertime and $76 \%$ and $87 \%$ for the wintertime data in 2010 and 2011, respectively. The first factor (F1) explained that most of the variance $(51 \div 64 \%)$ had high loadings of most elements investigated, however, with their different combination. We have named it regional background dust as the elements: $\mathrm{Ca}$, $\mathrm{K}, \mathrm{Mn}, \mathrm{Fe}, \mathrm{Zn}, \mathrm{Cu}, \mathrm{Pb}, \mathrm{Br}$, with the highest factor loadings can be related to a dust mixture of different origin and represent the main types of the pollution sources in the region. The elements $\mathrm{Ca}, \mathrm{K}$, and $\mathrm{Fe}$ are believed to contribute to the soil component in summer and fly ash in winter $[16,17]$. Resuspension of roadway dust is also dominated by crustal elements $\mathrm{Si}, \mathrm{Fe}, \mathrm{Ca}, \mathrm{Na}, \mathrm{Mg}, \mathrm{Al}$, and $\mathrm{K}[18]$. Metals related to traffic emission are $\mathrm{Cu}, \mathrm{Zn}, \mathrm{Pb}$, and $\mathrm{Br}$ [18-20]. We can notice an increase in the concentrations of these elements in winter periods, which correspond to a decrease in the temperature measured. Much higher concentrations of $\mathrm{K}$, $\mathrm{Zn}, \mathrm{Cu}, \mathrm{Pb}, \mathrm{Br}$, the elements characteristic for different kind of combustion processes, demonstrate that local sources, including biomass/refuse burning, coal, and fuel combustion are very important in the winter. Generally, it is very difficult to distinguish between soil and fly ash contribution. However, resuspension of soil particles during wintertime, particularly when the ground is frozen, seems to be less important process than combustion. The second factor (F2) explained from 13 to $30 \%$ of the variance and was probably associated with industrial pollution sources because $\mathrm{Cu}, \mathrm{Pb}$, 


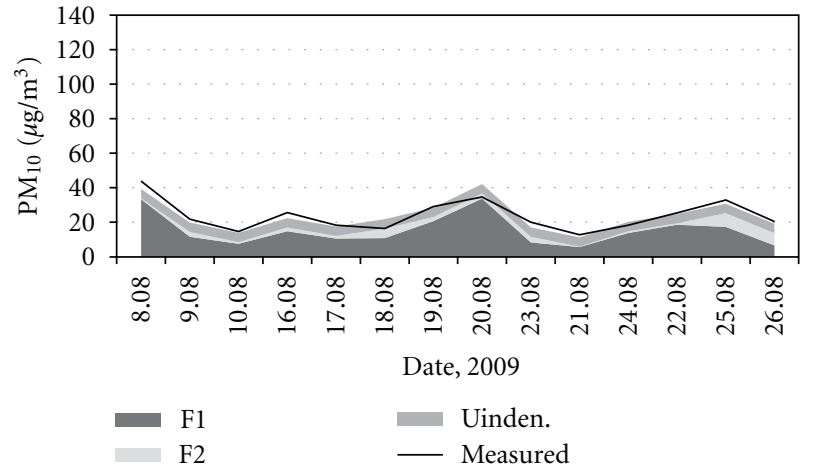

(a)

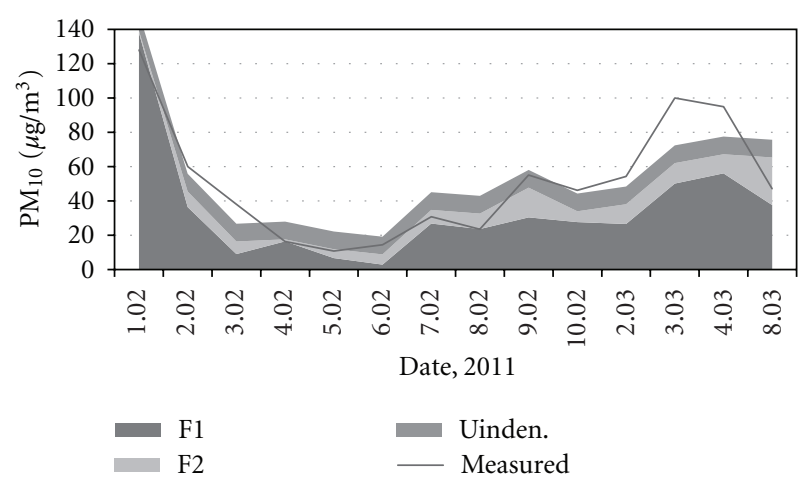

(b)

Figure 3: Daily source contributions to $\mathrm{PM}_{10}$ obtained by FAMLRA and measured by gravimetry for summer 2009 and winter 2011.

$\mathrm{Cr}, \mathrm{Mn}, \mathrm{Fe}$, and As are known to have industrial origin. What is interesting, these metals can represent different types of pollution sources.

Daily contributions of each source to ambient $\mathrm{PM}_{10}$ in Brzezina were estimated using FA-MLRA methodology [7]. Figure 3 shows an example of time series of the contributions of the identified sources for the summer period in 2009 and winter in 2011. On the basis of daily contributions, the average mass contributions of each source (SC-source contribution) were calculated and the results are summarized in Table 3 (the last raw). It can be seen in Table 3 that the average mass contribution of distant industrial emission sources was $12 \%$ and $15 \%$ in the summer 2009, 2010 and $6 \%$ and $20 \%$ in the winter 2010, 2011. Background dust contributed with $61 \%$ or $31 \%$ of total $\mathrm{PM}_{10}$ mass during the summer campaigns. However, nonidentified sources contributed with about $55 \%$ in the summer 2010 . It was probably due to high concentrations of sulphates, nitrates, and a certain amount of organic carbon which are characteristics secondary pollutants and are formed, especially in the summer, when solar radiation and the temperature are high. Secondary pollutants are usually indicative for a long distance transport. However, these pollutants were not measured.

Local combustion sources contributed with $79 \%$ in winter 2010 and 55\% in winter 2011, reflecting serious local problem associated with $\mathrm{PM}_{10}$ air pollution. Generally good compatibility was found between the measured $\mathrm{PM}_{10}$ concentrations by gravimetry and estimated by FA_MLRA (Figure 3 ). The squared correlation coefficient, $R^{2}$, was 0.80 and 0.72 for summer and winter data, respectively.

Now, the question is what industrial sources could contribute to total $\mathrm{PM}_{10}$ mass. Trajectory cluster analysis, conditional probability functions (CPF), and potential source contribution functions (PSCF) have been successfully used to identify transport paths and source areas [21-23]. These techniques demand long-term data, but we had only two weeks pollutant concentration time series. Thus, we defined the potential source localization function (PSLF) similarly to CPF [21]:

$$
\operatorname{PSLF}_{i j}=\frac{n_{i j}}{m_{j}},
$$

where, $n_{i j}$ is the number of cases with wind, " $j$ " direction connected with high daily concentrations of the species " $i$ " (the 75th percentile); $m_{j}$-is the total number of cases with " $j$ " wind direction. Thus, the PSL function can be interpreted as a probability describing the local wind direction as aprobable source localization direction. At first, we calculated the wind direction statistics based on one-hour data for each day during field studies. Wind directions came from Wroclaw Airport, Starachowice, about $10 \mathrm{~km}$ in the south direction. Then, we extracted days with high measured values of $\mathrm{PM}_{10}$ and selected elemental concentrations (above the 75 th percentile). At the end, we computed the backward trajectories using the HYSPLIT-4 model [10] for the episodic days and assessed the pollution source areas most likely to be upwind of the receptor. Figure 4(a) presents the PSL plots of $\mathrm{PM}_{10}$ and arsenic during summer 2009. $\mathrm{PM}_{10}$ concentrations greater than $28 \mu \mathrm{g} / \mathrm{m}^{3}$ (the 75 th percentile) were observed more frequently for the south-eastern wind sector and corresponded to wind speed values less than $2 \mathrm{~m} / \mathrm{s}$. Although southeastern and eastern wind dominated (see the wind rose in Figure 2), the PSL plots for $\mathrm{PM}_{10}$ show that the whole south-east sector was associated with elevated $\mathrm{PM}_{10}$ levels. Arsenic in higher concentrations (above $4,8 \mu \mathrm{g} / \mathrm{m}^{3}-$ the 75 th percentile) was more frequently connected with south-western winds which confirms that its origin is different than the main $\mathrm{PM}_{10}$ components. Arsenic can be released to air from various industrial sources (e.g., coal combustion, smelter, and mining activities) and pesticide application. Arsenic episodes on August, 18/19 and 26/27, corresponded to trajectories presented in Figure 5. 36-hour back trajectories were calculated by the HYSPLITT model for air masses ending over Brzezina at $200 \mathrm{~m}$ height level. From the data presented in Figure 5, it becomes obvious that that the recorded high values of As concentrations are probably due to dust transported from western directions. The nearest stationary source is a copper smelter located upwind (W) $50 \mathrm{~km}$ of the receptor (Legnica copper smelter).

The highest $\mathrm{PM}_{10}$ concentrations measured during the summer period in 2010 (Figure 4(b)) were more frequently connected with the south-eastern wind sector with the speed values below $2 \mathrm{~m} / \mathrm{s}$. Arsenic was not detected, but lead, which represents the other origin (together with $\mathrm{Cu}$ ) than the remaining measured $\mathrm{PM}_{10}$ components, was mainly 


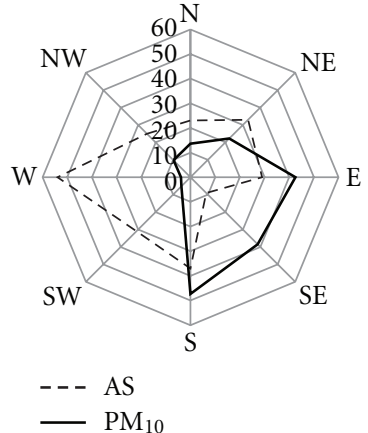

(a)

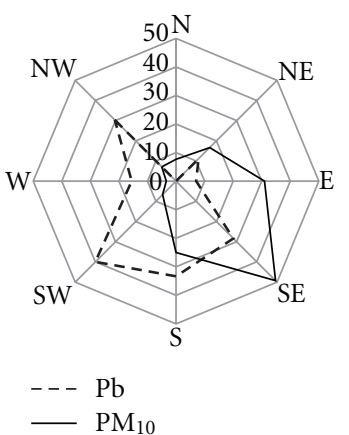

(b)

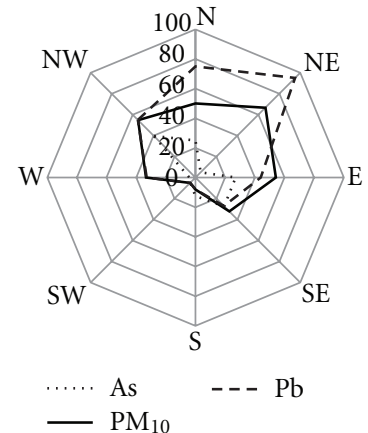

(c)

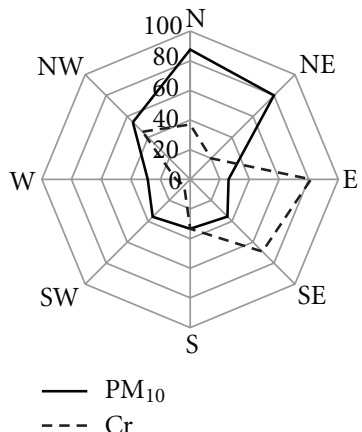

(d)

Figure 4: PSL plots (\%) of: (a) $\mathrm{PM}_{10}$ and arsenic during summer 2009; (b) $\mathrm{PM}_{10}$ and $\mathrm{Pb}$ during summer 2010; (c) $\mathrm{PM}_{10}$ and $\mathrm{As}$, $\mathrm{Pb}$ during winter 2010; (d) $\mathrm{PM}_{10}$ and Cr during winter 2011.

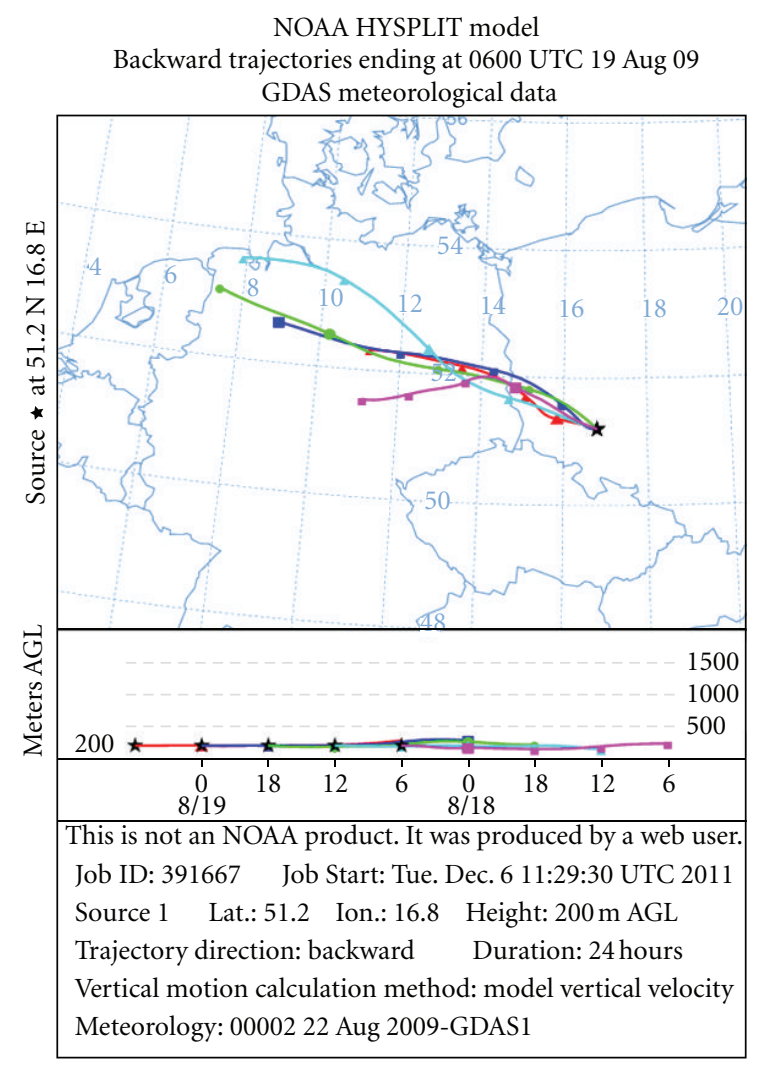

(a)

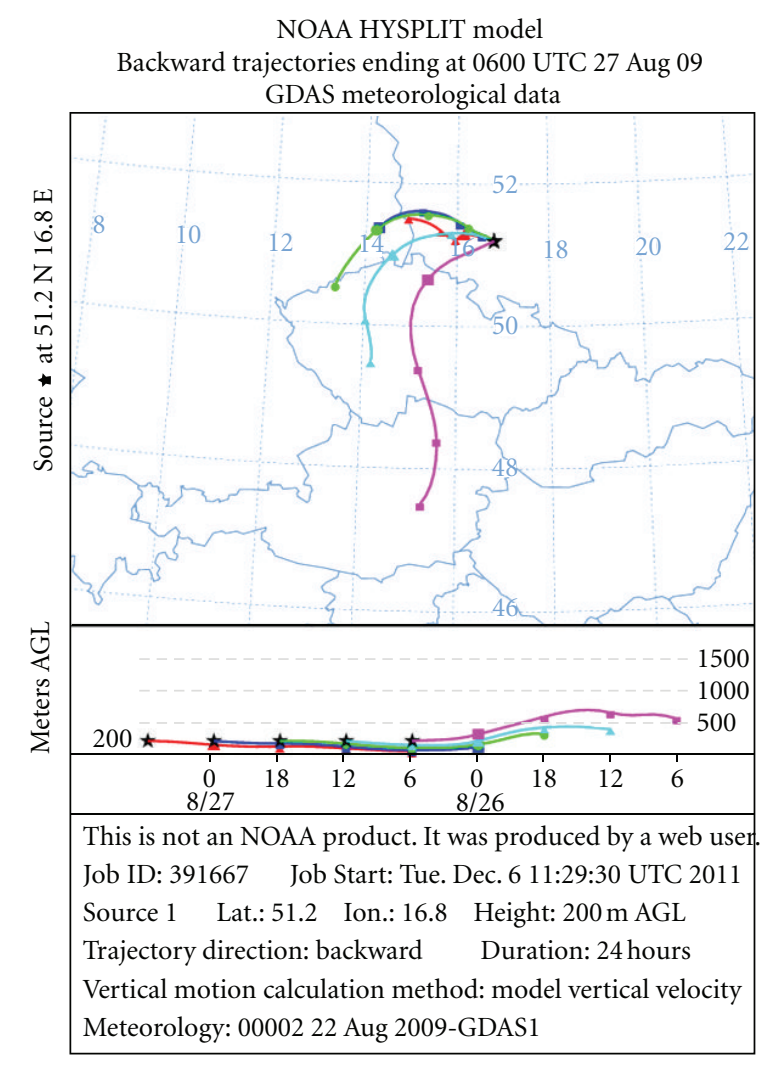

(b)

Figure 5: $24 \mathrm{~h}$ backward trajectories for the days with the highest As concentrations (19 August 2009 and 27 August 2009) arriving at the rural site at 06:00 UTC (08:00 LT).

advected with air masses from the south and south-western direction. There are no appropriate emissions inventories and thus, it is difficult to appoint the likely significant $\mathrm{Pb}$ and $\mathrm{Cu}$ sources which can include nonferrous metal smelting and processing or solid waste incineration. Lead episodes on August 10, 2010 corresponded to trajectories presented in Figure 6.

In winter 2010 the situation was different. Figure 4(c) shows that air masses contributing to worst-case arsenic concentrations tend to originate to the southeast and north- west of the village. However, it seems that very high As concentrations (above $10 \mu \mathrm{g} / \mathrm{m}^{3}$ ) can originate rather from local sources than regional ones, and probably from man-made local combustion devices. This source category includes incineration of various types of domestic refuse which is so common in small villages. Very low temperatures and low wind speeds resulted in small vertical mixing and in very high As concentrations as well as other elements. The diurnal variations of other $\mathrm{PM}_{10}$ components were similar to those of $\mathrm{PM}_{10}$. As an example, $\mathrm{Pb}$ is shown in Figure 4(c). $\mathrm{PM}_{10}$ 


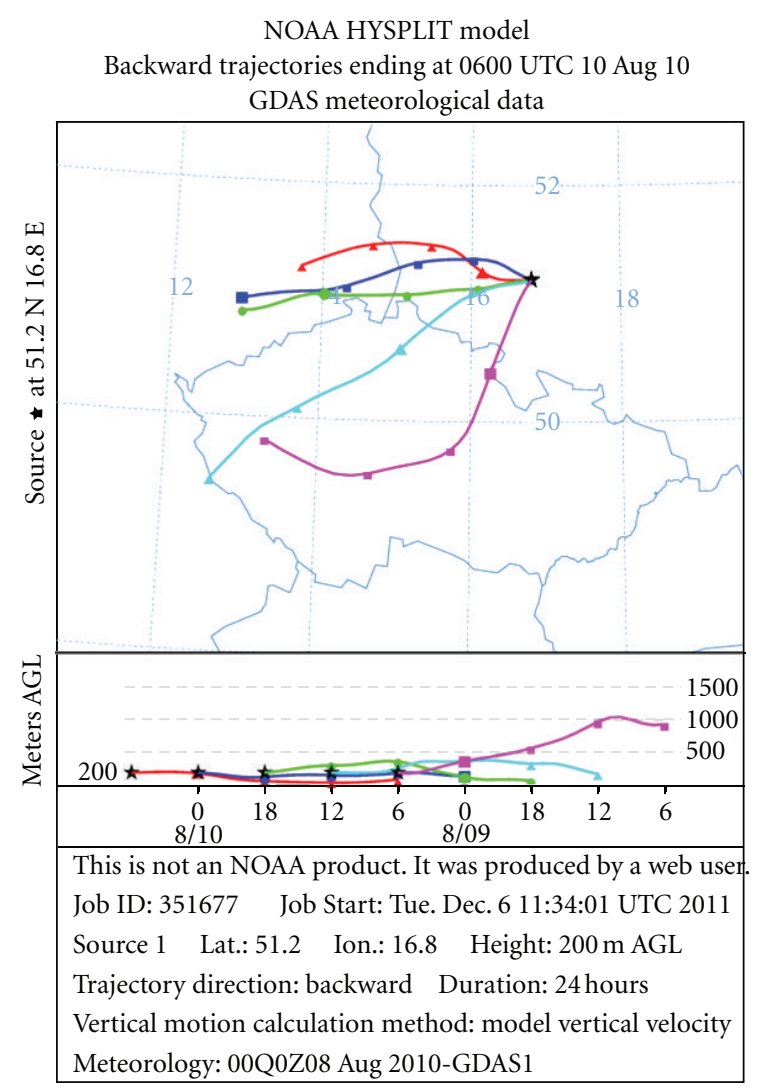

FIGURE 6: $24 \mathrm{~h}$ backward trajectories for the day with the highest $\mathrm{Pb}$ concentrations (10 August 2010) arriving at the rural site at 06:00 UTC (08:00 LT).

episodes, as well as $\mathrm{Pb}$, were more frequently monitored when wind was blowing from the north and north-east. The PSL plots for $\mathrm{Br}$ and $\mathrm{Zn}$ were very similar to that of $\mathrm{Pb}$ and are not shown here. It identifies the whole village Brzezina as the potential $\mathrm{PM}_{10}$ and $\mathrm{Pb}, \mathrm{Br}, \mathrm{Zn}$ pollution source and supports the idea that combustion processes are the major sources of $\mathrm{PM}_{10}$ and some elements.

Most interesting results were obtained for winter 2011 data. Although the western winds prevailed during this period (Figure 2(d)), major contributing directions for $\mathrm{PM}_{10}$ were from north as shown in Figure 4(d) similarly to 2010 data (Figure 4(c)). The most important wind directions for the elevated concentrations of Cr (above $20 \mu \mathrm{g} / \mathrm{m}^{3}$ the 75th percentile), which represents the industrial source (together with $\mathrm{Mn}$ and $\mathrm{Fe}$ ), were from the east and southeast. This direction appointed Wrocław with some metallurgical industrial plants. However, pollution source recognition is a very subjective process and strongly influenced both by the interpreter of the results and knowledge of the site.

\section{Conclusions}

Generally, the concentrations of $\mathrm{PM}_{10}$ at the rural site were high and showed strong variability during the seasons of the year exceeding the European Union air quality daily $\mathrm{PM}_{10}$ standard of $50 \mu \mathrm{g} / \mathrm{m}^{3}$ in winter periods. The seasonal variation in the rural atmosphere was clearly inducted by the local emissions from winter which was confirmed by the potential source localization calculations. The PSL plots identified the whole village as the potential contributor of $\mathrm{PM}_{10}$ mass and $\mathrm{Pb}, \mathrm{Br}, \mathrm{Zn}$, As concentrations and supported the idea that combustion processes are the major sources of $\mathrm{PM}_{10}$ and some elements in wintertime.

The evidence on regional transport of some toxic metals was provided for each season. However, it was found difficult to appoint the potential emission sources using only wind rose data. Two receptor modeling techniques PSLF and FA-MLRA were applied, and the results obtained were in general in good agreement, showing that some metals in higher concentrations were more frequently connected with different wind direction than the main $\mathrm{PM}_{10}$ components that confirmed their different origin as appointed by FA.

Air pollution problem is not only typical for the village under interest. Wood burning along with domestic refuse and the poorest and cheapest types of fuel is probably widely present in individual heating houses not only in Poland. This phenomenon undoubtedly contributes to high concentrations of $\mathrm{PM}_{10}$ and the high abundance of many elements in air in the winter which can pose serious health problems.

\section{Acknowledgments}

This work was partially financed by International Atomic Energy Agency project number RER/2/005 and Polish Ministry of Science and Higher Education. The authors gratefully acknowledge the NOAA Air Resources Laboratory for the access to READY website (http://ready.arl.noaa.gov/HYSPLIT_traj..php) used in this publication.

\section{References}

[1] K. Miller, D. Siscovick, L. Sheppard et al., "Mortality effects of longer term exposures to fine particulate air pollution: review of recent epidemiological evidence," Inhalation Toxicology, vol. 19, no. SUPPL. 1, pp. 33-38, 2007.

[2] C. A. Pope III, D. G. Renlund, A. G. Kfoury, H. T. May, and B. D. Horne, "Relation of heart failure hospitalization to exposure to fine particulate air pollution," American Journal of Cardiology, vol. 102, no. 9, pp. 1230-1234, 2008.

[3] WHO, Air Quality Guidelines Global Update, 2005, http:// www.euro.who.int/__data/assets/pdf_file/0005/78638/E90038 .pdf.

[4] C. Varotsos, C. Tzanis, and A. Cracknell, "The enhanced deterioration of the cultural heritage monuments due to air pollution," Environmental Science and Pollution Research, vol. 16, no. 5, pp. 590-592, 2009.

[5] C. Tzanis, C. Varotsos, M. Ferm, J. Christodoulakis, M. N. Assimakopoulos, and C. Efthymiou, "Nitric acid and particulate matter measurements at Athens, Greece, in connection with corrosion studies," Atmospheric Chemistry and Physics Discussions, vol. 9, no. 4, pp. 14683-14711, 2009.

[6] L. Samek, "Chemical characterization of selected metals by Xray fluorescence method in particulate matter collected in the area of Krakow, Poland," Microchemical Journal, vol. 92, no. 2, pp. 140-144, 2009. 
[7] G. D. Thurston and J. D. Spengler, "A multivariate assessment of meteorological influences on inhalable particle source impacts," Journal of Climate and Applied Meteorology, vol. 24, no. 11, pp. 1245-1256, 1985.

[8] S. M. Almeida, C. A. Pio, M. C. Freitas, M. A. Reis, and M. A. Trancoso, "Source apportionment of fine and coarse particulate matter in a sub-urban area at the Western European Coast," Atmospheric Environment, vol. 39, no. 17, pp. 31273138, 2005.

[9] S. M. Almeida, C. A. Pio, M. C. Freitas, M. A. Reis, and M. A. Trancoso, "Approaching $\mathrm{PM}_{2.5}$ and $\mathrm{PM}_{2.5-10}$ source apportionment by mass balance analysis, principal component analysis and particle size distribution," Science of the Total Environment, vol. 368, no. 2-3, pp. 663-674, 2006.

[10] R. Draxler and G. Rolph, HYSPLIT (HYbrid Single-Particle Lagrangian Integrated Trajectory) Model access via NOAA ARL READY Website, NOAA Air Resources Laboratory, Silver Spring, Md, USA, 2011, http://ready.arl.noaa.gov/HYSPLIT .php.

[11] M. Braniš and M. Domasová, "PM10 and black smoke in a small settlement: case study from the Czech Republic," Atmospheric Environment, vol. 37, no. 1, pp. 83-92, 2003.

[12] M. Braniš, M. Domasová, and P. Řezáčová, "Particulate air pollution in a small settlement: the effect of local heating," Applied Geochemistry, vol. 22, no. 6, pp. 1255-1264, 2007.

[13] H. Hauck, A. Berner, T. Frischer et al., "AUPHEP-Austrian Project on Health Effects of Particulates-general overview," Atmospheric Environment, vol. 38, no. 24, pp. 3905-3915, 2004.

[14] B. Gomiscek, A. Frank, H. Puxbaum, S. Stopper, O. Preining, and H. Hauck, "Case study analysis of PM burden at an urban and a rural site during the AUPHEP project," Atmospheric Environment, vol. 38, no. 24, pp. 3935-3948, 2004.

[15] WIOS Report (Voivodeship Inspectorate for Environment Protection Report), Environment Quality in Lower Silesian Voivodeship, 2009, http://www.wroclaw.pios.gov.pl/.

[16] M. Vallius, N. A. H. Janssen, J. Heinrich et al., "Sources and elemental composition of ambient PM2.5 in three European cities," Science of the Total Environment, vol. 337, no. 1-3, pp. 147-162, 2005.

[17] B. A. Begum, P. K. Hopke, and W. Zhao, "Source identification of fine particles in Washington, DC, by expanded factor analysis modeling," Environmental Science and Technology, vol. 39, no. 4, pp. 1129-1137, 2005.

[18] G. C. Lough, J. J. Schauer, J.-S. Park, M. M. Shafer, J. T. Deminter, and J. P. Weinstein, "Emissions of metals associated with motor vehicle roadways," Environmental Science and Technology, vol. 39, no. 3, pp. 826-836, 2005.

[19] J. Sternbeck, A. Sjödin, and K. Andréasson, "Metal emissions from road traffic and the influence of resuspension-results from two tunnel studies," Atmospheric Environment, vol. 36, no. 30, pp. 4735-4744, 2002.

[20] G. Lammel, A. Rohrl, and H. Schreiber, "Atmospheric lead and brominee in Germany. Post-abatement levels, variabilities and trends," Environmental Science and Pollution Research, vol. 9, pp. 397-404, 2002.

[21] D. Lucey, L. Hadjiiski, P. K. Hopke, J. R. Scudlark, and T. Church, "Identification of sources of pollutants in precipitation measured at the mid-Atlantic US coast using potential source contribution function (PSCF)," Atmospheric Environment, vol. 35, no. 23, pp. 3979-3986, 2001.

[22] S. S. Abdalmogith and R. M. Harrison, "The use of trajectory cluster analysis to examine the long-range transport of secondary inorganic aerosol in the UK," Atmospheric Environment, vol. 39, no. 35, pp. 6686-6695, 2005.

[23] Y. Xie and C. M. Berkowitz, "The use of conditional probability functions and potential source contribution functions to identify source regions and advection pathways of hydrocarbon emissions in Houston, Texas," Atmospheric Environment, vol. 41, no. 28, pp. 5831-5847, 2007. 


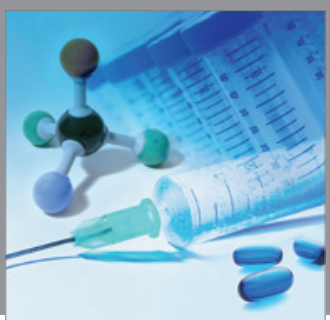

International Journal of

Medicinal Chemistry

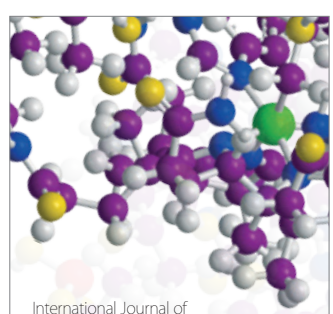

Carbohydrate Chemistry

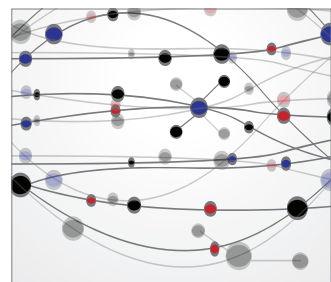

The Scientific World Journal
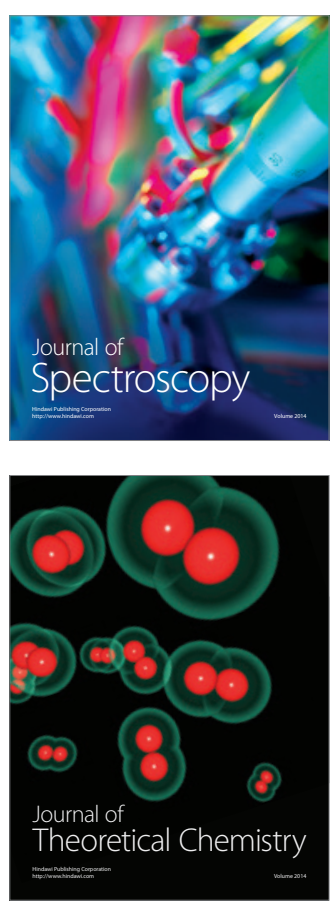
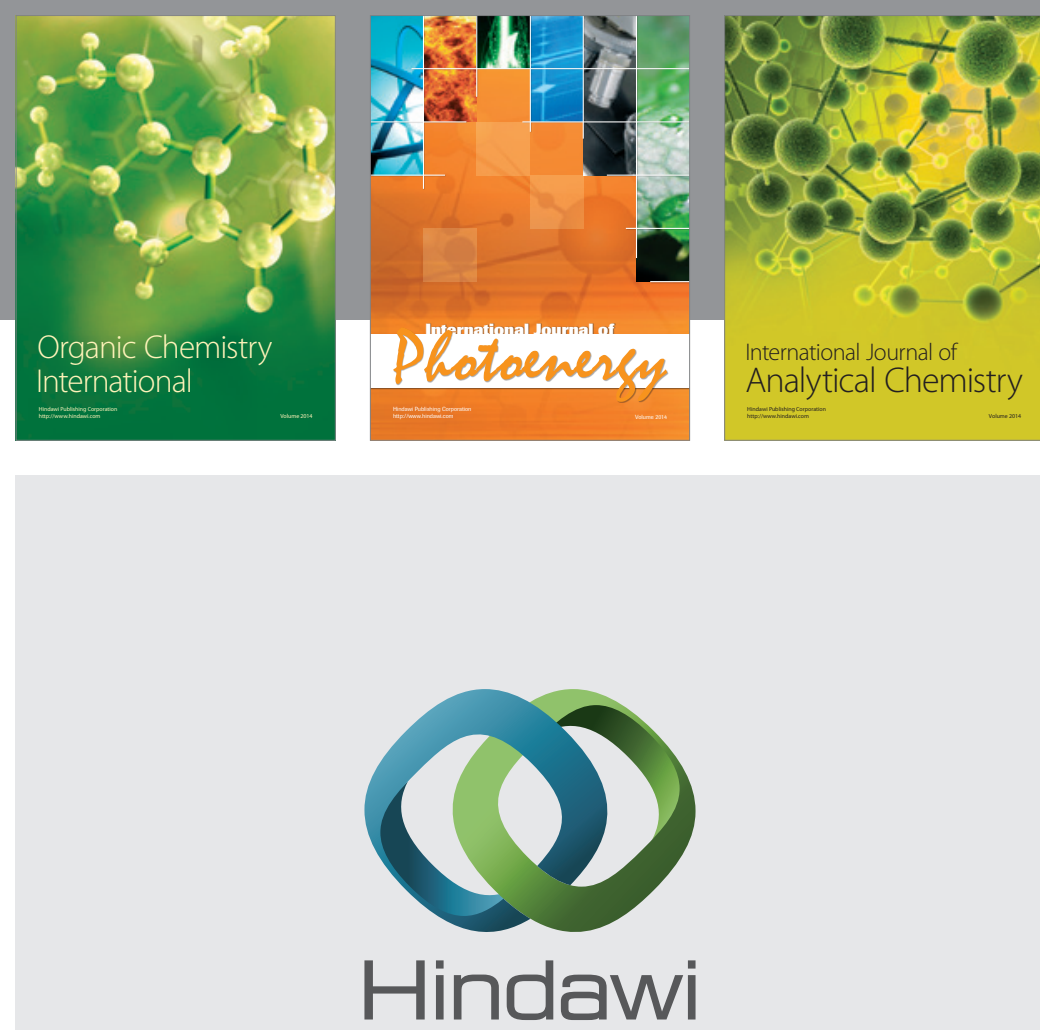

Submit your manuscripts at

http://www.hindawi.com
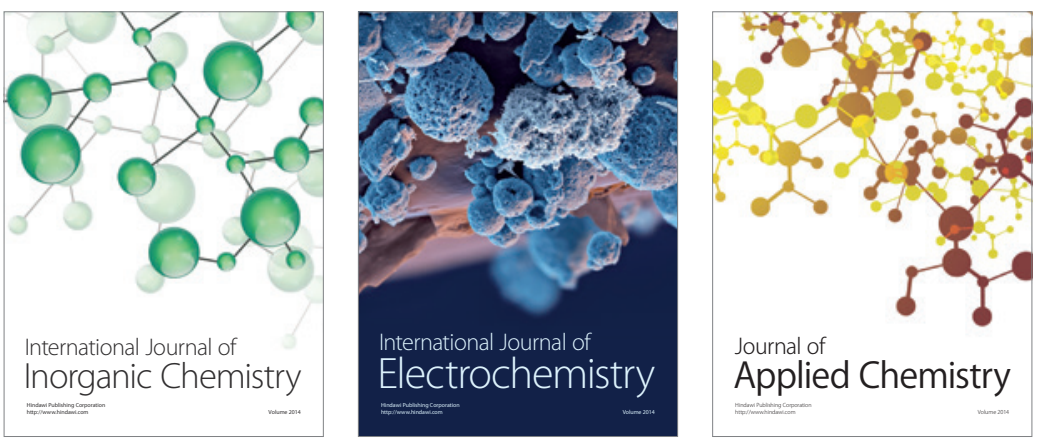

Journal of

Applied Chemistry
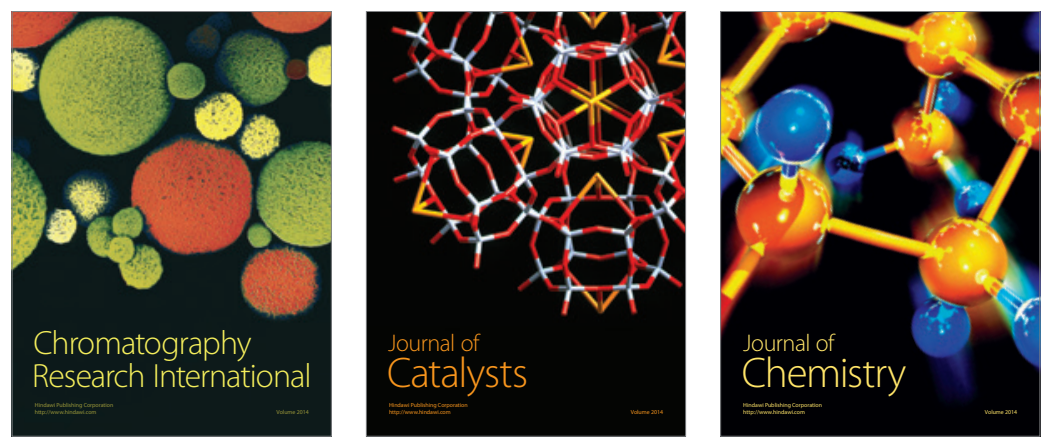
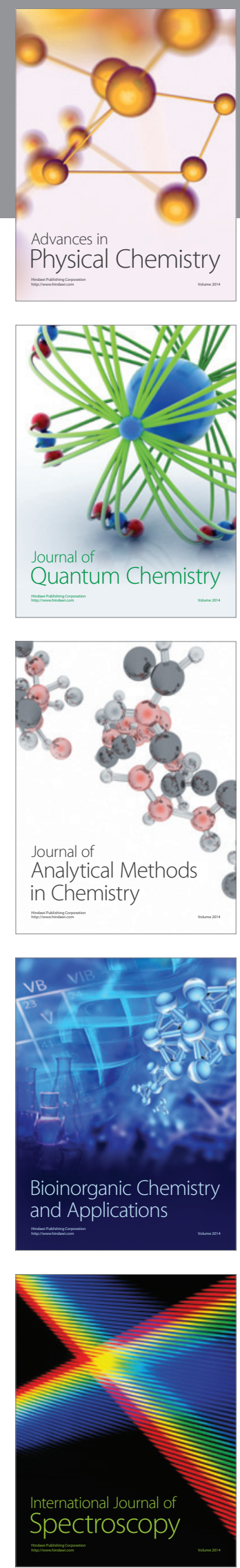